\title{
ILMU PENGETAHUAN, TEORI DAN PENELITIAN \\ Firman Firman
}

\section{(Jurusan Bimbingan dan Konseling FIP Universitas Negeri Padang) \\ Email : firman@konselor.org}

\section{A. Pendahuluan}

Peneliti dituntut memiliki kepekaan dan kemauan mendapat jawaban secara ilmiah terhadap berbagai masalah dalam kehidupan masyarakat. Sebelum melaksanakan penelitian, peneliti dibekali dengan berbagai pengetahuan dan keterampilan serta teori-teori sesuai dengan bidang kajian yang ditekuninya. Salah satu pengetahuan yang harus dikuasi peneliti dalam pengembangan ilmu yang ditekuninya menyangkut dengan pemahaman hakekat ilmu pengetahuan, teori dan penelitian. Uraian berikut membahas ilmu pengetahuan, fungsi dan tujuan ilmu, fungsi dan tujuan penelitian, hubungan ilmu dengan penelitian serta bangun deduktif dan induktif.

\section{B. Ilmu Pengetahuan}

Pada prinsipnya ilmu dan pengetahuan mempunyai perbedaan. Herman Soewandi (1996) menjelaskan pengetahuan merupakan pembentukan pemikiran assosiatif yang menghubungkan atau menjalin sebuah pemikiran dengan kenyataan atau dengan pemikiran lain, berdasarkan pengalaman yang berulang-ulang tanpa pemahaman mengenai kausalitas (sebab-akibat) yang hakiki dan universal. Sedangkan ilmu adalah akumulasi pengetahuan yang menjelaskan kausalitas (hubungan sebab-akibat) dari suatu obyek secara sistematis berdasarkan metodemetode tertentu.

Di dalamkehidupan sehari-hari pengetahuan ilmiah disepadankan dengan ilmu. Ilmu memiliki sifat, yaitu : (1) menjelejahi dunia emperik tanpa batas sejauh dapat ditanghkap oleh panca indera, (2) tingkat kebenaran bersifat relatif, (3) ilmu menemukan proposisi-proposisi yang teruji secara emprik (Sodjawo,2001, Herman Suwandi,Rusidi,1996). 
Ilmu tidak hanya berfungsi sebagai sarana berfikir tetapi ilmu harus dapat menjelaskan fakta dengan prosedur dan struktur ilmiah. Garna (1996:4) menjelaskan struktur dan prosedur ilmu pengetahuan terlihat sebagai berikut :

\section{Tahap Pengetahuan- Ilmu- Filsafat Ilmu}

Filsafat ilmu

Ilmu pengetahuan

Pengetahuan
Analisis Prosedur,logika eksplanasi

Eksplanasi Data

Fakta, Pengalaman Hidup

Komponen-komponen dalam pembangunan ilmu adalah fakta, teori, fenomena dan konsep. Fenomena adalah gejala atau kejadian yang ditangkap indera manusia serta diabstraksikan dengan konsep-konsep. Konsep merupakan penyederhanaan dari fenomena. Sedangkan fakta adalah data yang dapat dibuktikan secara emperik. Teori merupakan seperangkat konsep, definisi dan proposisi yang berhubungan satu sama lain sebagai jalinan dari keseluruhan fakta. Teori berfungsi untuk meramalkan, mengarahkan, mengkonseptualisasikan fenomena yang ditangkap oleh indera manusia. Teori berguna dalam memberikan penjelasan menemukan fakta, sedangkan fakta memberi inspirasi untuk mengubah, menolak, mengkonstruksi serta mengantikan teori yang sudah ada. Proposisi merupakan hubungan sebab akibat yang bersifat umum, sebagai ungkapan dari kaitan dua variabel/konsep atau lebih.

Ilmu pengetahuan memiliki ciri, diantaranya: (1) mempunya batasan dan ruang lingkup yang jelas, (2) metoda dalam membuktikan kebenaran, (3) sistematis serta (4) terbuka untuk dikaji kebenaranya. Oleh karena itu syarat utama dari ilmu pengetahuan harus konsisten dengan teori sebelumnya serta memiliki kesesuaian dengan fakta emperis.

Kebenaran ilmu pengetahuan tidak didasarkan oleh nilai-nilai etis tetapi tidak dapat dilepaskan dengan etika penggunaannya. Oleh karena itu seorang ilmuan dituntut memiliki kejujuran, keterbukaan serta memanfaatkan ilmu pengetahuan untuk kemaslahatan umat. Sehubungan dengan hal itu, seorang peneliti dituntut 
memilki kemampuan mempertahankan objektifitas ilmiah sehingga kesimpulankesimpulan yang diperoleh dari penelitian yang dilakukan sesuai dengan fakta emperis. Di sisi lain seorang peneliti juga dituntut memiliki kemampuan menyesuaikan diri dan terbuka dengan ide baru karena beratnya rintangan yang dilalui dalam penemuan kebenaran.

\section{Fungsi dan Tujuan Ilmu Pengetahuan}

Manusia diciptakan Tuhan dengan kesadaran sehingga memiliki kemampuan berfikir, berkehendak dan merasa. Kemampuan berfikir dimiliki masnusia menghasilkan ilmu pengetahuan. Logika digunakan manusia sebagai sarana meningkatkan ilmu pengetahuan. Sedangkan etika dan estetika digunakan manusia sebagai sarana memelihara perilaku dan mutu kesenian.

Hasrat keingintahuan tersebut mendorong manusia menyelesaikan berbagai permasalahan sehingga timbul ilmu pengetahuan. Soerjono Soekamto, (1990:8) menjelaskan setelah memperoleh pengetahuan timbul keinginan mencari kebenaran, dengan cara : (1) penemuan secara kebetulan, (2) untung-untungan, (3) pendapat dari orang memiliki otoritas/kewibawaan tertentu, (4) spekulatif, (5) pengalaman, (6) penelitian Ilmiah.

Ilmu pengetahuan berguna untuk menguji dan menghasilkan kebenaran pernyataan dunia emperis manusia, dengan cara: otoriter, mistik, logika-rasional dan ilmiah. Pengujian dan penemuan secara otoriter dilakukan oleh pemegang kekuasaan tertentu dengan cara mencari dan menguji ilmu pengetahuan dengan menggaitkan kemampuan membuat pernyataan dengan pemilik kedudukan sosial lainnya. Prosedur penanaman otoritas dilakukan melalui doa, petisi, etiket, upacara dan sebagainya. Pengetahuan tersebut akhirnya berakibat praktis dalam membantu meruntuhkan otoritas lainnya. Walaupun demikian sebelum terjadinya pengakuaan kebenaran masih terjadi sejumlah penolakan, sehingga sangat tergantung kepada posisi sosial pembuat pengetahuan dalam meyakinkan.

Penemuan kebenaran secara mistik dilakukan melalui penemuan dan pengujian dunia emperis melalui ketegangan halusinasi, sebagian dihubungkan dengan cara otoriter, sejauh dapat memohon pengetahuan yang berasal dari para 
wali, perantara, dewa-dewa dan otoritas lain yang memiliki kekuatan gaib. Cara ini tergantung dengan pemurnian rituallistik dan prosedur kepekaan sipemakai. Sedangkan secara logika-rasional, penilaian bagi pernyataan yang dianggap benar terutama berada pada prosedur dimana pernyataan itu dibuat, dan prosedur itu terpusat pada kaidah logika formal. Cara ini berhubungan dengan cara otoriter dan mistik sejauh memiliki dasar penerimaan prosedur dan aksioma yang mengandung logika formal.

Kebenaran secara ilmiah ditemukan dengan mengabungkan suatu kepercayaan pada fakta emperis yang dipermasalahkan dengan prosedur (metode) menghasilkan pernyataan tersebut. Penekanan penanaman metode dalam hal ini adalah bila nilai kebenaran dua atau lebih dianggap bersaing, maka plihanan terhadap salah satu sangat tegantung dengan penilaian kolektif dan pengulangan prosedur yang menghasilkan item informasi itu. Dalam kenyataannya, semua metode ilmu pengetahuan sering dianggap sebagai persetujuan kultural yang ketat. Hasil perubahan didasarkan kritik terhadap item-item pengetahuan yang dilakukan secara kolektif dengan hasil yang relatif utuh. Pemusatan kritik didasarkan metode yang dianggap sebagai esensial ilmu pengatahuan.

Metoda ilmiah secara sistemastis menghilangkan padangan pribadi sehingga akhirnya tergambar kebenaran universal. Mengigat keterbatasan manusia sesungguhnya tidak mungkin melakukan objektivitas secara murni, perkiraan tentang hal itu hanya berupa kesepakatan diantara para ilmuwan. Oleh karena itu, kontrol metodologi dalam proses ilmiah akan menghilangkan padangan pribadi sehingga akhirnya kesepakatan. Ketentuan membentuk skala, menentukan sampel, pengukuran, menaksir parameter, menarik kesimpulan induksi dan deduksi secara logis sebagai dasar utama mengkritik, menolak dan menerima item-item informasi ilmu pengetahuan itu. Apabila dua komponen informasi masih dianggap saling bersaing, sangat tergantung daya ketangguhan dalam mempertahankan penolakan dan terus berulang melakukan pengamatan. Pada gilirannya kebenaran-kebenaran yang dinyatakan diterima masyarakat ilmiah didasarkan pembuktian secara emperik. 
Popper menjelaskan segala sesuatu diakui sebagai emperis atau ilmiah jika mampu diuji oleh pengalaman. Suatu sistem emperis yang imiah harus memilki kemungkinan untuk ditolak oleh pengalaman (1961: 40-41).

Ilmu pengetahuan merupakan pengetahuan (knowledge) yang tersusun sistematis dengan menggunakan kekuatan pikiran serta dapat diuji dan dikontrol secara kritis. Soerjono Soekamto, 1990:6) menjelaskan pengetahuan dengan buah

pikiran tersebut berbeda, karena tidak setiap pikiran memerlukan pembuktian akan kebenaranya, walaupun demikian buah pikiran dan angan-angan merupakan bahan bagi ilmuwan melaksanakan kegiatan ilmiah yang akan dilakukannya.

\section{Hubungan Ilmu dengan Penelitian}

Pertumbuhan ilmu pengetahuan merupakan sumbangan kegiatan penelitian yang telah dilakukan ilmuan. Penelitian dengan menggunakan metode ilmiah secara sistematis untuk mengungkap rahasia dunia tidak dapat dipisahkan dengan pertumbuhan ilmu pengetahuan. Hal ini menunjukan ilmu pengetahuan menemukan pengetahuan-pengetahuan baru dalam bentuk dalil, teori atau generalisasi mengenai rahasia dunia, yang kebenarannya teruji secara ilmiah. Jumlah teori, dalil dan generalisasi yang ditemukan melalui penelitian oleh ilmuan sangat menentukan seberapa jauh rahasia dunia telah terungkap.

Pelaksanaan penelitian didasarkan oleh asumsi bahwa segala sesuatu gejala tidak berdiri sendiri tetapi dipengaruhi oleh berbagai faktor. Faktor yang belum dapat diungkapkan secara emprik akan menjadi objek penelitian. Penelitian pada dasarnya merupakan aktifitas dan metode berfikir untuk memecahkan suatu permasalahan yang belum ditemukan jawabannya .

Penemuan-penemuan rahasia dunia melalui pengalaman emperik tersebut dapat dijadikan sebagai bahan untuk meramalkan, mengendalikan dan menjelaskan kondisi yang akan terjadi. Temuan penelitian terhadap sesuatu masalah dapat menjadi landasan mengkaji masalah baru dan begitulah seterusnya. Penemuan demi penemuan silih berganti, masing-masing berfungsi untuk memekarkan penemuan sebelumnya. Penemuan ilmiah tidak menemukan kebenaran mutlak tetapi bersifat tentatif yang dapat berubah bila ditemukan data baru. 
Temuan baru dalam penelitian diperoleh melalui prosedur atau cara yang sistematis yang disebut dengan metodology. Istilah metodologi (methodology) dengan metoda (methods) tidak jarang tumpang tindih penggunaannya. Sebenarnya metodogi (methodology) merupakan studi yang logis dan sistematis tentang prinsipprinsip yang mengarahkan penelitian ilmiah, yang intinya terdiri dari : masalah, tinjauan pustaka, kerangka teori (jika ada), hipotesis (jika ada) dan cara penelitian. Sedangkan metoda (methods) merupakan cara untuk melakukan penelitian, menyangkut dengan bahan, alat, jalan penelitian, variabel penelitian dan analisis hasil.

Metoda penelitian pada prinsipnya menceritakan cara yang merupakan alat (tool) mencapai tujuan. Cara yang dilakukan dalam penelitian bervariasi dan tidak kaku serta tergantung dari objek formal ilmu pengetahuan tersebut, tujuan serta jenis data yang akan diungkapkan. Penelitian umumnya mengandung dua ciri, yaitu logika dan pengamatan emperis (Babbie, $1986: 16$ ).

Penelitian ditujukan memecahkan masalah yang dihadapi untuk pengembangan ilmu pengetahuan dan permasalahan umat manusia. Jawaban masalah tersebut menggunakan pendekatan ilmiah (scientific approach) yang pada gilirannya melahirkan metode ilmiah (scientific method). Upaya yang dilakukan dengan menggunakan metoda ilmiah disebut dengan penelitian ilmiah (scientific research).Penelitian ilmiah adalah suatu bentuk upaya penyelidikan (investigation) terhadap suatu pernyataan (proposisi) hipotesis yang dijadikan sebagai jawaban sementara suatu masalah. Membedakan dengan bentuk penyelidikan lain, ada beberapa ketentuan pokok yang harus dipenuhi oleh pelakunya, Pertama, penelitian itu harus dilakukan secara sistematis, terkontrol, dan kritis. Kedua, penelitian ilmiah menghasilkan kebenaran ilmiah, bersifat menerangkan (explanatory), memprediksi (predictive) dan mengontrol (controlling).

Penelitian ilmiah adalah kegiatan yang bersifat indrawi (empirical) maksudnya, jawaban masalah yang diperoleh melalui kegiatan ini merupakan keyakinan subyektif peneliti namun telah teruji dengan kenyataan-kenyataan objektif di luar dirinya. Dengan kata lain, setiap pernyataan peneliti haruslah selalu 
didasarkan pada kebenaran yang diperoleh melalui pengujian dan penjelajahan yang bersifat empiris (empirical inquiry and test).

Keyakinan terhadap jawaban suatu masalah memerlukan upaya pengujian di luar dirinya sendiri. Dengan kata lain sesuatu yang dianggap benar secara subyektif dan teoritis perlu diverifikasi seberapa jauh kebenaran yang diduga itu ditemui pada kenyataan objektif (objective reality) di lapangan. Bila proposisi hipotesis-teoritis itu didukung oleh data yang ditemukan di lapangan barulah proposisi itu diterima sebagai jawaban masalah secara relatif meyakinkan. Namun bagaimanapun juga temuan tersebut masih tetap terbuka untuk diujikan lagi pada kesempatan lain. Barulah kemudian setelah menempuh ujian berkali-kali, proposisi tersebut dapat dijadikan sebagai teori keilmuan yang baru. Karena itu tidak mustahil temuan suatu penelitian akan ditolak oleh data pada kesempatan lain. Bila terjadi demikian maka kemungkinan tertolaknya temuan yang semula diharapkan akan menjadi unsur baru khasanah pengetahuan tidak dapat dihindarkan.

Kegiatan penelitian yang dilalui peneliti secara umum adalah ; (1) persiapan, (2) pelaksanaan, (3) pengolahan data,(4) pembuatan laporan dan (4) sosialisasi hasil penelitian.

\section{E. Bangun Deduktif dan Induktif.}

Penelitian ditujukan menjawab permasalahan secara emperik, melalui dua pendekatan yang digunakan manusia untuk menemukan jawaban sesuatu permasalahan, yaitu metode deduksi yang dikenal dengan Silogisme Aristoteles. Melalui pendekatan ini dijelaskan penemuan baru, melalui kesimpulan deduktif sehingga memerlukan pengetahuan atau dalil umum (premis mayor) yang menjadi dasar berpijak kesimpulan-kesimpulan khusus yang dibagun. Dari premis mayor ke kesimpulan deduksi dijembatani oleh Primis Minor.

Contoh :

Premis Mayor $\quad$ : Nasib manusia tergantung oleh perjuangannya

Premis Minor : : Anita juga manusia

Kesimpulan deduktif : Nasib anita tergantung oleh perjuangannya 
Kebenaran premis mayor sangat menentukan kebenaran kesimpulan deduktif, oleh karena itu kesalahan silogisme dalam penggunaan premis perlu diperhatikan. Sudjarwo (2001:19) menjelaskan kesalahan yang muncul adalah: (1) kesalahan isi menyangkut dengan kesalahan materi dari premis, (2) kesalahan bentuk (formal) menyangkut kesalahan jalannya deduksi. Di sisi lain dogma tempat dasar berpijaknya kesimpulan sulit digoyahkan maka pengetahuan baru kurang berkembang karena dalil umum yang dianut membatasi gerak laju akulmulasi dan kebenaran pengetahuan manusia.

Kelemaham metode berfikir deduktif menyebabkan lahirnya metode induktif dipelopori oleh Francis Bacon $(1561,1626)$. Bacon menjelaskan seharusnya para ilmuawan tidak menerima premis sebelumnya yang telah memiliki kebenaran mutlak. Kesimpulan yang benar dan akurat dapat diperoleh dengan pengumpulan fakta melalui pengamatan langsung. Kesimpulan umum dalam penerapan metode Induksi diperoleh dari hasil pemeriksaan fakta-fakta emperik (induksi).

\section{Contoh :}

Setiap orang kaya yang diamati mengikuti mode dan pemilih teman.

Kesimpulannya orang kaya mengikuti mode dan pemilih teman.

Mekipun induksi dengan deduksi saling mengisi dan selalu terdapat berdampingan, namun perlu dibedakan titik tolak, jalan pikirannya, syarat-syarat untuk mencapai kebenaran, tingkat kepastian yang dapat dicapai memang berbeda antara kedua pola pikir tersebut. Deduksi merupakan cara berfikir dari pernyataan yang bersifat umum ditarik kesimpulan menjadi khusus.

Poespoprodjo dan Gilarso (1987 : 15) menjelaskan pola dasar deduksi merupakan proses pemikiran dari pengetahuan yang lebih umum menyimpulkan pengetahuan yang lebih khusus.

Kaum rasionalis menyusun pengetahuan menggunakan metode deduktif. Premis yang dipakai dalam penalarannya didapat dari ide yang menurut anggapannya jelas dan dapat diterima. Ide tersebut menurut kaum rasionalis bukanlah ciptaan manusia dan fungsi pikiran manusia hanyalah mengenali prinsip tersebut dan 
menjadi pengetahuannya. Ide menurut kaum rasionalis bersifat apriori dan prapengalaman yang didapatkan manusia lewat penalaran rasional. Dalam penalaran deduksi masalah utama adalah evaluasi dari kebenaran premis-premis yang dipakai.

Jujun S.Suriasumatri (1993:49) menjelaskan penarikan kesimpulan secara deduktif menggunakan pola befikir yang dinamakan silogismus. Silogismus disusun dari dua pernyataan dan sebuah kesimpulan. Pernyataan yang mendukung silogismus disebut premis yang dapat dibedakan premis mayor dan minor. Kesimpulan merupakan pengetahuan yang didapat dari penalaran deduktif berdasarkan kedua premis tersebut.

Contoh : 1

1. Semua makhluk mempunyai mata

2. Si Polan adalah seorang makhluk

3. Jadi Si Polan mempunyai mata

Contoh : 2

1. Semua makhluk ciptaan Tuhan

2. Manusia adalah Makhluk

3. Manusia itu ciptaan Tuhan
(Premis mayor)

(Premis minor)

(Kesimpulan )

(Premis mayor)

(Premis minor)

(Kesimpulan)

Apabila 1 dan 2 benar maka dengan sendirinya 3 akan benar pula. Jika 1 dan 2 benar tetapi 3 salah maka terjadi suatu kontradiktif, dengan arti kata kesimpulan tidak sesuai dengan fakta yang sebenarnya. Sehubungan dengan hal itu, ciri kunci dari deduksi adalah valid atau sah. Walaupun demikian logika dan deduksi saja tidak dapat mengukuhkan kebenaran mengenai keterangan-keterangan fakta. Sesuatu yang dapat diberikan oleh logika, dalam hubungan ini apabila premis-premisnya benar, selanjutnyas kesimpulan mesti benar. Apakah premise-premise itu benar atau tidak, bukanlah suatu hal yang dapat ditetapkan dengan bantuan logika.

Kelemahan metode deduksi adalah kesimpulan yang didapat tidak lebih dari perjanjian-perjanjian atau pengalaman saja. Pada sistem deduksi kesimpulan yang benar dapat saja tidak masuk akal bila digunakan premis yang tidak masuk akal. 
Contoh :

1. Semua yang berkaki adalah hewan (Premis major)

2. Manusia berkaki dua

(Premis minor)

3. Manusia itu hewan

(Kesimpulan )

Penggunaan metode induktif secara ilmiah ternyata memiliki kelemahan karena banyak fakta emperis yang tidak dapat digunakan menjelaskan suatu fenomena. Sehubungan dengan hal itu Charles Darwin menarik deduktif teoritik atau hipotesis lalu mengumpulkan fakta yang relevan menguji kebenaran hipotesis tersebut. Beranjak dari fakta emperis tersebut ada kemungkinan hipotesis diterima atau ditolak kebenarannya. Selanjutnya metoda Deduktif-Induktif itulah yang disebut dengan metode ilmiah. Wujud kongkrik dari metode ilmiah adalah penelitian yang dilakukan secara terancang dan sistematis bertujuan menemukan pengetahuan baru, dimana permasalahan yang dikaji, metodologi dan hasil temuan dilaporkan/dikomuniaksikan sehingga terbuka untuk diketahui dan diuji kebenarannya.

Logika berfikir deduksi dan induksi salah satu atau keduanya harus tercermin dari hasil penelitian.Logika berfikir deduktisi digunakan dalam perumusan hipotesis dengan cara melakukan deduksi dengan berbagai teori. Sedangkan logika induksi berlangsung dalam alur pengujian hipotesis dengan adanya data dan sampel ataupun kasus. Oleh karena itu dapat disimpulkan penelitian adalah aktifitas menelaah sesuatu masalah dengan menggunakan metode ilmiah secara sistematis untuk menemukan pengetahuan baru.

\section{E. Unsur-unsur dalam Ilmu, Teori. Operasional dan Observasi.}

Pembicaraan tentang ilmu berhubungan dengan aspek ontologi, epistimologi dan axiologi. Secara ontologis ilmu hanya dapat menjelajahi sebatas pengalaman manusia. Luasnya objek jelajahan ilmu tersebut maka dibatasi atas bebeberapa bagian yang selanjutnya menjadi bidang kajian disiplin ilmu tersendiri. Permulaan perkembangan ilmu hanya membagi atas ilmu sosial dan ilmu alamiah. Kondisi selanjutnya semakin terfokus sehingga menjadi berbagai cabang ilmu. Pencerminan 
aspek ontologi dari penelitian ilmiah terlihat dari pembatasan objek dan ruang lingkup penelitian penelitian.

Cara penemuan ilmu dengan aturan-aturan ilmiah merupakan objek kajian epistimologi. Hal ini dalam penelitian tercermin pada penggunaan metode yang didasarkan dengan pendekatan deduktif dan induktif. Sedangkan axiologi ilmu objek kajiannya ditujukan manfaat temuan untuk kemaslahatan umat manusia. Pencerminan aspek axiologi dalam penelitian terlihat dari perumusan kegunaan penelitian yang ditujukan untuk pengembangan ilmu serta kegunaan praktis lainnya dalam wujudkan kesejahteraan manusia.

Penelitian pada hakekatnya dilaksanakan dengan menggunakan model tradisional dan dinamis (Babbie,1986:30-31). Model tradisional pada prinsipnya mengandung tiga unsur, yaitu : pemahaman teoritis, operasionalisasi dan pengujian hipotesis. Kenyataannya pelaksanaan penilitian walaupun memenuhi ketiga unsur tersebut sifatnya tidaklah demikian kaku karena proses penelitian tersebut adalah dinamis. Teori berkembang diawali oleh pemahaman teori, selanjutnya menghasilkan hipotesis. Melalui hipotesis diperoleh cara melakukan observasi yang pada akhirnya menghasilkan generalisasi. Berdasarkan generalisasi, teori tersebut didukung atau ditolak sehingga menghasilkan dukungan teori atau membentuk teori baru. Begitu pulalah sebaliknya.

Penelitian dihubungkan oleh dua metode logika, yaitu deduksi dan induksi yang dipergunakan secara bergantian. Lingkaran keilmuan dalam pemanfaatan kedua metoda tersebut dapat dilihat pada gambar berikut : 
Dewasa ini model pendekatan dinamislah yang sering digunakan oleh ilmuan dalam menemukan kebenaran. Wallace (1971 :16-24) menjelaskan proses menemuakankebenaran ilmu pengetahuan dan penelitian berlandaskan pada metode tertentu. Proses menemukan kebenaran tersebut terlihat pada gambar berikut : 


\section{DAFTAR KEPUSTAKAAN}

Chalmers, A.F (1983) : Apa itu yang Dinamakan Ilmu ?. Jakarta : Hasta Mitra

Garna, Judistira K (1996) : Ilmu-ilmu Sosial Dasar-Konsep-Posisi. Bandung : Program Pascasarjana Universitas Padjadjaran.

Nasution (1982) : Metode Research. Bandung : Jemmars.

Sanafiah Faisal (1995) : Format-format Penelitian Sosial, dasar dan Aplikasi. Jakarta : Rajawali Pers.

S.Suriasumantri, Jujun. (1993) : Filsafat Ilmu Sebuah Pengantar Populer . Jakarta : Pustaka Sinar Harapan.

Sudjarwo, (2001) : Metodologi Penelitian Sosial. Bandung: Mandar maju

Soekanto, Soerjono (1990) : Sosiologi Suatu Pengantar. Jakarta : Rajawali Pers.

Sumardjono,Maria S.W, (1989) : Pedoman Pembuatan Usulan Penelitian. Yogyakarta : UGM Yogyakarta.

Poespoprodjo,W. (1991) : Logika Scientifika. Bandung : Penerbit PT.Remaja Rosdakarya.

Poespoprodjo, W (1987) : Logika Ilmu Menalar. Bandung : Remaja Karya.

Wallace, Walter L. (1990) : Metoda Logika Ilmu Sosial. Jakarta : Bumi Aksara.

Winardi (1979) : Pengantar Metodologi Research. Bandung : Penerbit Alumni. 
MAKALAH

\section{ILMU PENGETAHUAN, TEORI DAN PENELITIAN}

Oleh : Dr. Firman. MS.

( Kepala Bidang Kemasyarakatan

Balitbang Prop. Sumbar)

Disampaikan dalam Pelatihan Metodologi Riset

Untuk Dosen Di Lingkungan Politeknik Universitas Andalas Padang

Tanggal 5-7 Mei 2003 
